\title{
Docetaxel Distribution Following Intraperitoneal Administration in Mice
}

\author{
Payam Zahedi, Raquel De Souza, Micheline Piquette-Miller and Christine Allen \\ Department of Pharmaceutical Sciences, Leslie Dan Faculty of Pharmacy, University of Toronto, Toronto, Canada
}

Received, December 3, 2010; Revised, February 10, 2010; Accepted, February 23, 2011; Published, February $23,2011$.

\begin{abstract}
Purpose. Intraperitoneal (IP) chemotherapy with high molecular weight lipophilic antineoplastic agents such as the taxanes has shown promise in clinical trial evaluation for treatment of localized peritoneal cancers. We have previously developed an IP injectable hydrogel formulation (PoLigel) for sustained peritoneal delivery of docetaxel (DTX), and observed significant efficacy in murine models of ovarian cancer when compared to Taxotere ${ }^{\circledR}$, the FDA approved formulation of DTX. In order to understand the relationship between drug distribution and efficacy, the current study compares the tissue distribution and pharmacokinetics of DTX administered IP in the PoLigel or Taxotere ${ }^{\circledR}$ formulations. Methods. The PoLigel was prepared by blending a water-soluble chitosan derivative, egg phosphatidylcholine and lauric aldehyde with DTX (drug to material ratio 1:8 w/w). DTX concentrations in plasma, heart, liver, spleen, stomach, intestine, kidney and peritoneal layer were measured over a five day period following IP administration of the PoLigel and Taxotere ${ }^{\circledR}$ formulations in CD-1 female mice. Results. Three days after Taxotere ${ }^{\circledR}$ administration, no detectable levels of DTX were seen in plasma, while sustained DTX plasma levels of $0.06 \mu \mathrm{g} / \mathrm{ml} \pm 0.01$ per day were observed with PoLigel. At five days post Taxotere ${ }^{\circledR}$ administration, only intestine, stomach and peritoneal layer showed detectable DTX concentrations whereas all tissues and plasma showed sustained DTX levels in mice that received PoLigel. DTX concentrations that resulted from PoLigel administration were significantly higher in the peritoneal cavity and 200 fold higher than concentrations found in plasma. Conclusions. Overall, the PoLigel formulation increases tissue and plasma drug retention and provides sustained DTX levels compared to the clinically used Taxotere ${ }^{\circledR}$ formulation. The sustained DTX levels seen in the peritoneal cavity following IP administration of the PoLigel may be responsible for the improvement in efficacy that has been observed in our previous studies.
\end{abstract}

\section{INTRODUCTION}

Intraperitoneal (IP) chemotherapy involves the administration of therapeutic agents directly into the peritoneal cavity to achieve high local concentrations of drug for an extended period of time while minimizing systemic exposure. Docetaxel (DTX), an anti-mitotic cytotoxic drug, has been investigated for IP therapy (1) due to its high molecular weight $(807.9 \mathrm{~g} / \mathrm{mol})$, hydrophobic nature (water solubility: 5-6 $\mu \mathrm{g} / \mathrm{ml}$ ) and hepatic metabolism (over 90\%) (2-4). Taxotere ${ }^{\circledR}$ is the clinically used formulation of DTX, and when administered IP in patients with cancers localized to the peritoneal cavity, results in higher drug concentrations in the peritoneal cavity than in the systemic circulation. A Phase I study by Morgan et al. in patients with peritoneal malignancies including ovarian and gastric cancers showed the mean pharmacokinetic advantage, defined as the ratio of peritoneal area under the concentration time curve (AUC) to plasma AUC over a 24 hour period, to be 181 following IP administration of Taxotere ${ }^{\circledR}$ (5). Similarly, Fushida et al. observed a pharmacokinetic advantage of 515 (i.e. $\mathrm{AUC}_{\text {peritoneal,0-24h }} / \mathrm{AUC}_{\text {plasma,0-24h }}$ ) in gastric cancer patients following IP administration of Taxotere $\mathbb{}$ (6). Although IP administration of bulky, hydrophobic drugs such as DTX initially results in a high pharmacokinetic advantage, these drugs are eventually absorbed through peritoneal capillaries into the systemic circulation, followed by quick elimination via hepatic metabolism $(7,8)$.

Prolonged drug exposure has been shown to increase tumor responsiveness to chemotherapeutics (9-13). For this reason, lengthening the time that chemotherapeutics are retained within the peritoneal

Corresponding Author: Dr. Christine Allen, Leslie Dan Faculty of Pharmacy University of Toronto, 144 College Street, Toronto, Ontario, Canada; E-mail address: cj.allen@utoronto.ca 
cavity may be beneficial for treatment of peritoneal localized cancers. One approach that has been used to increase the retention time of drugs in the peritoneal cavity is formulation of drugs in excipients such as surfactants or advanced delivery systems. For example, Taxotere ${ }^{\circledR}$ consists of DTX solubilized in the non-ionic surfactant polysorbate 80 . To date there are only reports on the levels of DTX in the peritoneal cavity and plasma up to 24 hours post IP administration of Taxotere ${ }^{\circledR}$ (14-16). Longer studies on Taxotere $\AA$ tissue and plasma distribution following IP administration are warranted. As well, polysorbate 80 has been shown to cause toxicity, alter the cellular uptake of DTX and interfere with its activity $(10,17-19)$. To further increase the retention of drugs in the peritoneal cavity and circumvent issues with polysorbate 80 , drug delivery vehicles such as nanoparticles, microparticles and hydrogels have been explored. Nanoparticles can prolong the peritoneal residence time of free drug; however, they are typically cleared within two days through absorption into the lymphatic circulation (20-22). Microparticles have been shown to lead to further improvements in peritoneal retention of drugs in comparison to nanoparticles $(21,22)$. However, they have also been associated with drawbacks including foreign body reactions, residual polymer filaments in abdominal tissues several months after treatment (23), and development of peritoneal adhesions which can be potentially lethal $(21,24)$. To date the majority of the microparticle systems evaluated for IP administration of drugs have been formed from polyester-based polymers and as such the issues with these systems may in part be attributed to the materials employed (25-28).

The incorporation of free drugs or nanoparticulate-based delivery systems into implantable or injectable hydrogels can further prolong retention times. Yeo et al. accomplished this by incorporating nanoparticles within an in situ crosslinkable hydrogel, which increased the retention time of the nanoparticles within the peritoneal cavity from two days (21) to one week (29). Similarly, Grant et al. incorporated drugloaded nanoparticles into a polymer-lipid implantable film (30), which provided peritoneal drug release over several weeks following IP implantation in mice $(28,31)$. With this goal in mind, we have recently developed and characterized an injectable biocompatible and biodegradable polymer-lipid hydrogel formulation (PoLigel) for localized IP delivery of DTX (13). Sustained delivery of DTX using the PoLigel formulation has resulted in greater inhibition of disease progression, compared to Taxotere ${ }^{\circledR}$ administered IP at equivalent doses, in two distinct orthotopic models of ovarian cancer (10). In order to understand the relationship between drug distribution and efficacy, the current study compares the tissue distribution and pharmacokinetics of DTX administered IP in the PoLigel formulation and Taxotere ${ }^{\circledR}$.

\section{MATERIALS AND METHODS}

\section{Materials}

DTX was purchased from Jari Pharmaceutical Co. (Jiangsu, China). Chitosan was purchased from Marinard Biotech Inc. (Quebec City, Canada). Taxotere ${ }^{\circledR}(40 \mathrm{mg} / \mathrm{ml})$ was purchased from SanofiAventis. Egg phosphatidylcholine (ePC), glycidyltrimethylammonium chloride (GTMAC), hydrogen peroxide and lauric aldehyde (LA) were purchased from Sigma-Aldrich Chemical Co. (Oakville, Canada). Scintigest Tissue Solubilizer was purchased from Thermo Fisher Scientific (Waltham, USA). Ready Safe Scintillation Cocktail was purchased from Beckman Coulter (Mississauga, Canada). All other chemicals were reagent grade and used as received.

\section{Preparation of Polymer-Lipid Formulation}

The polymer-lipid hydrogel formulation (i.e. PoLigel) was prepared as outlined elsewhere (13). In brief, a water-soluble chitosan derivative (WSC) (32) was dissolved in distilled deionized water to prepare a $4.2 \%(\mathrm{w} / \mathrm{v})$ solution. DTX was dissolved in anhydrous ethanol and dried under nitrogen to form a thin layered film and then placed under vacuum for $24 \mathrm{~h}$ to remove any residual solvent. An ePC-LA solution (ePC to LA ratio of 1:4 w/w) was used to re-suspend the DTX film. Finally the WSC solution was added to the ePC-LA-DTX solution and vortexed for $1 \mathrm{~min}$ (drug to material ratio of 1:8 $\mathrm{w} / \mathrm{w})$. Samples were sterilized under UV-light (Sterilizer T209, Intercosmetics, Canada) for $3 \mathrm{~h}$ prior to use in animals.

\section{Analysis of Plasma and Tissue Distribution of Drug}

All animal studies were conducted in accordance with the guidelines of the University of Toronto 
Animal Care Committee and the Canadian Animal Care Council. Female CD-1 mice (6-8 weeks old, 20 g) purchased from Charles River (St. Constant, Canada) were used. Mice were injected IP (Total DTX dose: $7 \mathrm{mg} / \mathrm{kg})$ with PoLigel $(27 \mu \mathrm{L})$ or Taxotere ${ }^{\circledR}(18 \mu \mathrm{L})$ in the lower left quadrant of the peritoneal cavity, with an injection depth of $1 \mathrm{~cm}$ using a 25 gauge needle. In previous studies the PoLigel formulation was shown to provide sustained release of $7 \mathrm{mg} / \mathrm{kg}$ over a five day period (13). Each treatment group was further randomized according to the length of therapy $(1,3,6,12,18$, 24, 48, 72, 96 and 120 h). At specific time points, mice $(n=4)$ were anesthetized and sacrificed by exsanguinations via cardiac puncture. Plasma, heart, liver, spleen, stomach, intestine, kidney and peritoneal layer were collected for highperformance liquid chromatography (HPLC) analysis. HPLC work was conducted as outlined elsewhere (13). In summary, an Agilent Series 1100 HPLC (Agilent Technologies, Canada) equipped with a Waters $4.6 \mathrm{~mm}$ x $250 \mathrm{~mm}$ column (XTerra ${ }^{\circledR}$ MS $\mathrm{C}_{18}, 5 \mu \mathrm{m}$ particle size) and Waters $3.9 \times 20$ mm guard column (XTerra ${ }^{\circledR}$ MS $\mathrm{C}_{18}, 5 \mu \mathrm{m}$ particle size), Waters Dual Absorbance Detector 2487 (Waters, USA) and ChemStation software (Agilent Technologies, Canada) was used for analysis. The wavelength of detection for DTX was $227 \mathrm{~nm}$. A mobile phase of $60 \% 0.01 \mathrm{M}$ PBS $(\mathrm{pH}=10)$ and $40 \%$ acetonitrile was used with a flow rate of 1 $\mathrm{ml} / \mathrm{min}$ and an injection volume of $20 \mu \mathrm{l}$ per sample. An internal standard of paclitaxel (10 $\mu \mathrm{g} / \mathrm{ml}$ ) was used for all HPLC analysis. The limit of detection (LOD) was $5 \mathrm{ng} / \mathrm{ml}$ and $10 \mathrm{ng} / \mathrm{ml}$ for plasma and tissues, respectively. The limit of quantification (LOQ) was $10 \mathrm{ng} / \mathrm{ml}$ and $20 \mathrm{ng} / \mathrm{ml}$ for plasma and tissues, respectively.

\section{Analysis of Intraperitoneal Distribution of Drug} Twelve mice received PoLigel- ${ }^{3} \mathrm{H}-\mathrm{DTX}$ (Total DTX dose: $7 \mathrm{mg} / \mathrm{kg}, 0.002 \%{ }^{3} \mathrm{H}-\mathrm{DTX} \mathrm{w} / \mathrm{w}$ ) in the lower left quadrant of the peritoneal cavity, with an injection depth of $1 \mathrm{~cm}$ using a 25 gauge needle. At specific time points, mice $(n=4)$ were anesthetized and sacrificed by exsanguinations via cardiac puncture. Distal and proximal tissue sections (liver, intestine, kidney and peritoneal layer) with respect to the site of PoLigel injection (Figure 1B) were collected for analysis of radioactivity. Scintillation counting was used to quantify the amount of radioactivity in each tissue sample. Each tissue sample was homogenized at a $10 \% \quad(\mathrm{w} / \mathrm{v})$ concentration in deionized distilled water using a tissue homogenizer (Wheaton, USA). $100 \mu \mathrm{L}$ of tissue homogenate or plasma was added into scintillation vials containing $1.0 \mathrm{~mL}$ Scintigest Tissue Solubilizer solution. Samples were kept at $55^{\circ} \mathrm{C}$ for $2 \mathrm{~h}$, followed by the addition of $200 \mu \mathrm{L}$ of $30 \%(\mathrm{v} / \mathrm{v})$ hydrogen peroxide. The samples were kept at $55{ }^{\circ} \mathrm{C}$ for an additional $30 \mathrm{~min}$, after which each sample received $4 \mathrm{~mL}$ Ready Safe Scintillation Cocktail followed by scintillation counting (Beckman Coulter LS 5000TD, Beckman instruments Inc., USA). The amount of drug in each sample was quantified using a calibration curve.

\section{STATISTICAL ANALYSIS OF DATA}

Statistical analyses were performed using Statistical Package for the Social Sciences version 16.0 (SPSS Inc., USA). A two-sample t-test was used to measure statistical significance between pairs of results. For statistical analyses among three or more groups, one-way analysis of variance (ANOVA) was used and subsequent multiple comparisons with Bonferroni correction were performed if any statistical significance was detected by the ANOVA F-test. A p-value $<0.05$ was considered to be significant.

\section{RESULTS}

The plasma profile for Taxotere ${ }^{\circledR}$ showed a 3-fold higher DTX concentration compared to the PoLigel at 1 hour post-administration, and by 72 hours the levels in the plasma fell below the detection limit of the assay (Figure 2). Plasma levels of $0.140 \mu \mathrm{g} / \mathrm{ml} \pm$ 0.048 at 1 hour post PoLigel administration were measured and, by 24 hours, the DTX plasma levels decreased by two fold. Following this, sustained DTX plasma levels of $0.060 \mu \mathrm{g} / \mathrm{ml} \pm 0.010$ per day were observed (Figure 2). The distribution of DTX in tissues is shown in Figure 3. The average concentrations of drug in tissues for the first 24 hours following administration of Taxotere ${ }^{\circledR}$ were as follows: peritoneal layer $(2.5 \pm 1.1 \mu \mathrm{g} / \mathrm{g})$, stomach $(11 \pm 4 \mu \mathrm{g} / \mathrm{g})$, spleen $(8.9 \pm 1.3 \mu \mathrm{g} / \mathrm{g})$, intestines $(3.8 \pm 2.1 \mu \mathrm{g} / \mathrm{g})$, liver $(1.4 \pm 0.2 \mu \mathrm{g} / \mathrm{g})$, kidneys $(0.57 \pm 0.31 \mu \mathrm{g} / \mathrm{g})$ and heart $(0.45 \pm 0.16$ $\mu \mathrm{g} / \mathrm{g}$ ). At the end of the five day period, only intestine, stomach and peritoneal layer showed detectable DTX concentrations (Figure 3A). 


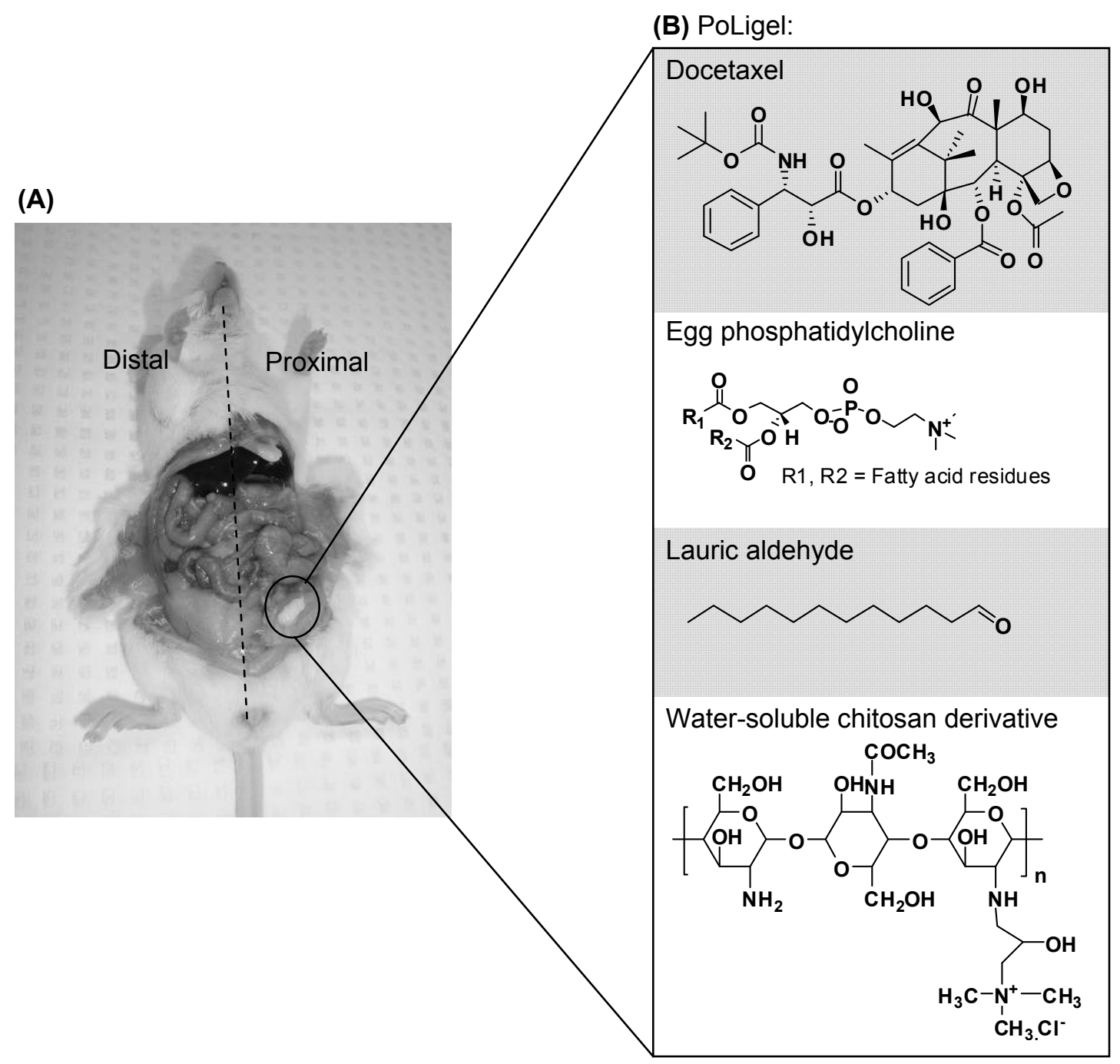

Figure 1. (A) Post-mortem view of the PoLigel in the peritoneal cavity of a female CD-1 mouse (distal and proximal is relative to site of PoLigel injection). (B) Chemical structures of drug and material components of the PoLigel.

The average concentration of drug in tissues for the first 24 hours following PoLigel administration was as follows: peritoneal layer $(3.8 \pm 0.9 \mu \mathrm{g} / \mathrm{g})$, stomach $(1.4 \pm 0.8 \mu \mathrm{g} / \mathrm{g})$, spleen $(0.66 \pm 0.32 \mu \mathrm{g} / \mathrm{g})$, intestines $(1.4 \pm 0.8 \mu \mathrm{g} / \mathrm{g})$, liver $(0.76 \pm 0.48 \mu \mathrm{g} / \mathrm{g})$, kidneys $(0.21 \pm 0.11 \mu \mathrm{g} / \mathrm{g})$ and heart $(0.077 \pm 0.07$ $\mu \mathrm{g} / \mathrm{g})$. DTX concentrations in the peritoneal layer were 200 fold higher than concentrations found in plasma. The distribution of DTX in the peritoneal cavity following IP administration of the PoLigel was also investigated. In order to assess this, tissues (i.e. peritoneal layer, kidney, liver and intestine) were separated into proximal and distal sections relative to the site of PoLigel injection (Figure 1). No statistically significant difference $(p>0.05)$ in
DTX concentration was seen between the proximal and distal sections of all tissues evaluated (Figure 4).

\section{DISCUSSION}

Localized IP dug delivery in a sustained manner can provide significant therapeutic advantages for peritoneal localized diseases by ensuring high drug concentrations at the target site, extended drug exposure, and lower systemic toxicity. Strategies to extend drug retention time in the peritoneal cavity using drug delivery systems such as nanoparticles, microparticles and hydrogels have been investigated $(13,20-22,30)$. 


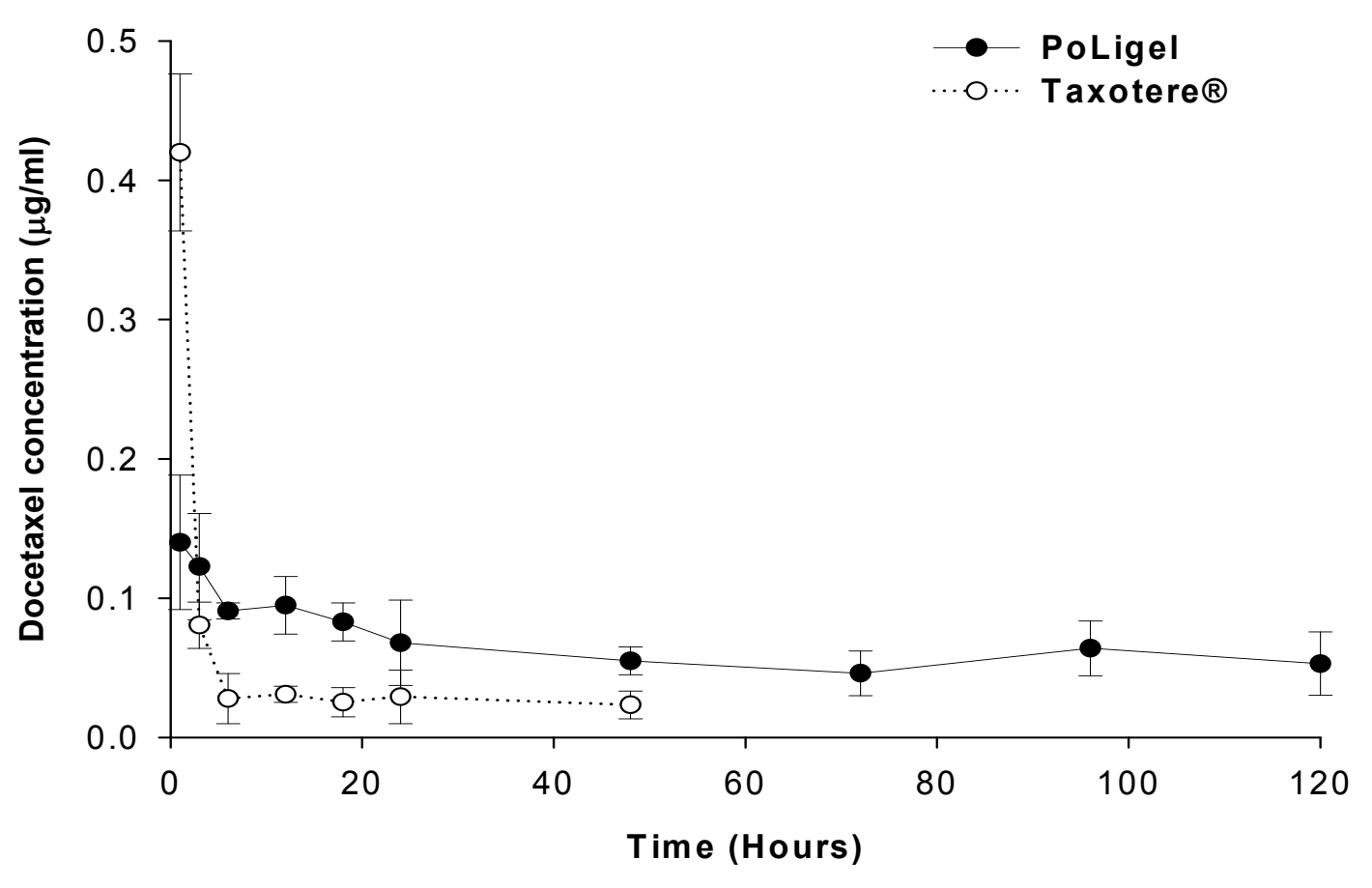

Figure 2. DTX plasma levels following IP administration of PoLigel or Taxotere ${ }^{\circledR}$ in female CD-1 mice (Total DTX dose: $7 \mathrm{mg} / \mathrm{kg})$. The results represent mean $\pm \mathrm{SD}(\mathrm{n}=4)$.

(A)

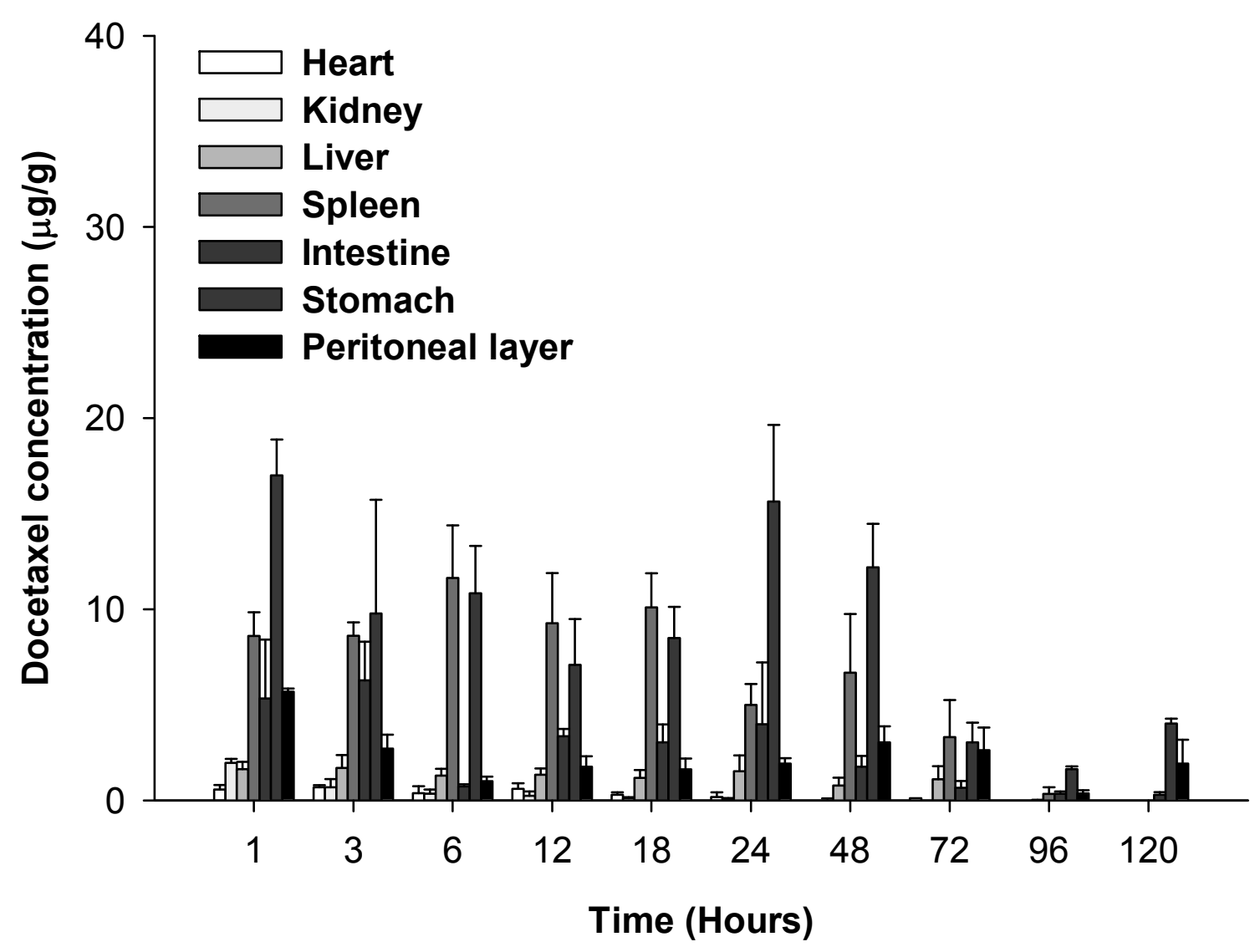


(B)

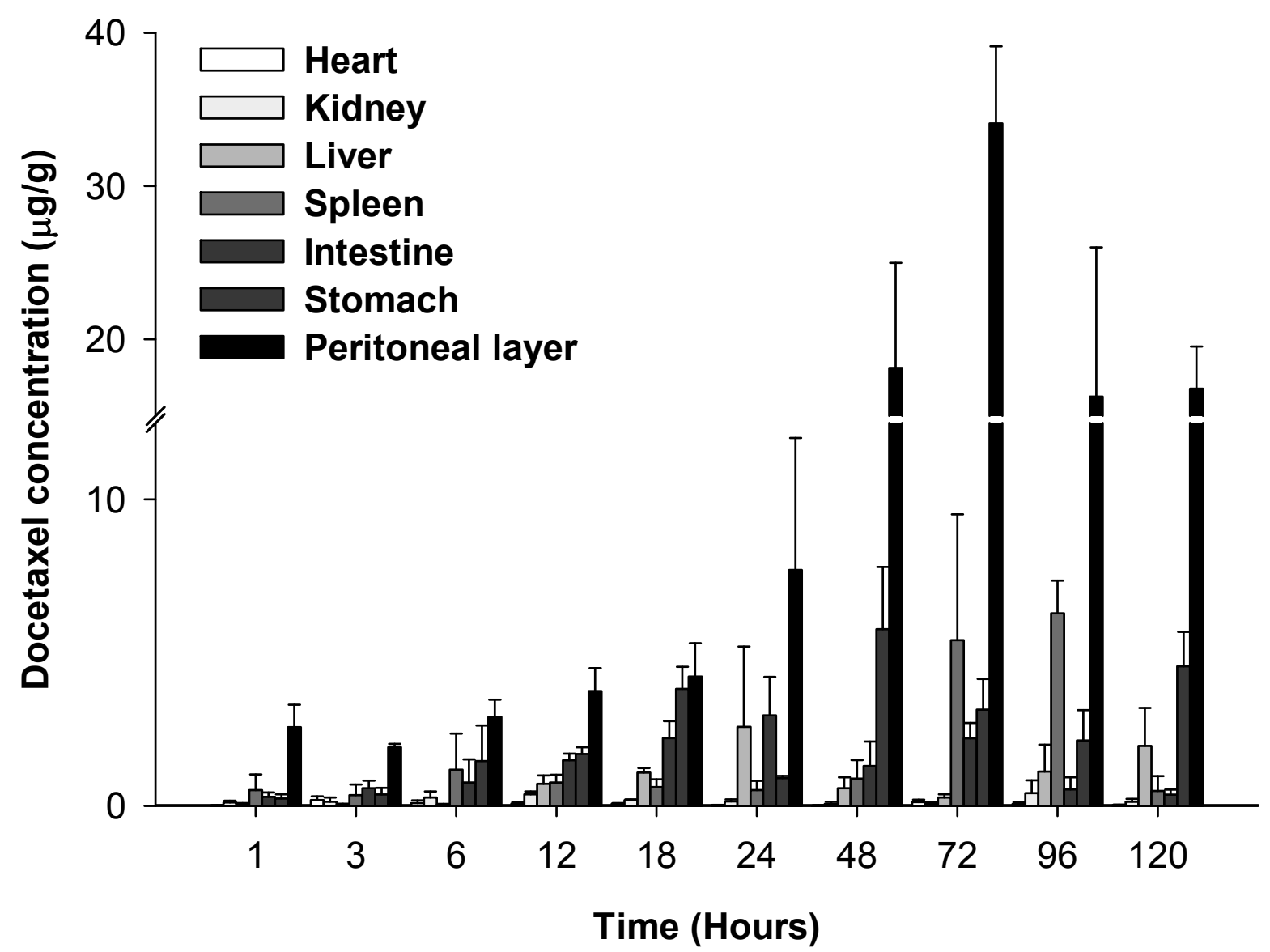

Figure 3. DTX tissue distribution following IP administration of (A) Taxotere ${ }^{\circledR}$ or (B) PoLigel in female CD-1 mice (Total DTX dose: $7 \mathrm{mg} / \mathrm{kg})$. The results represent mean $\pm \mathrm{SD}(\mathrm{n}=4)$.

(A)

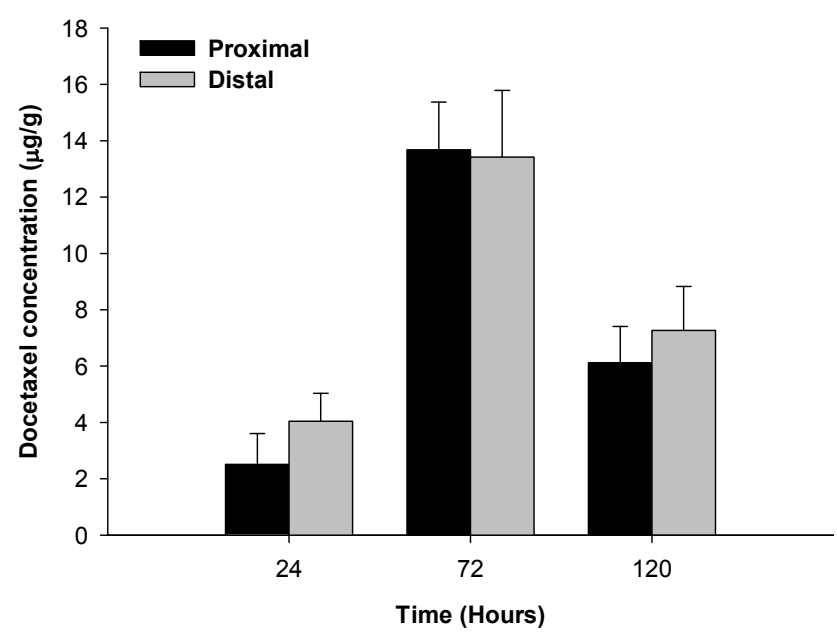

(B)

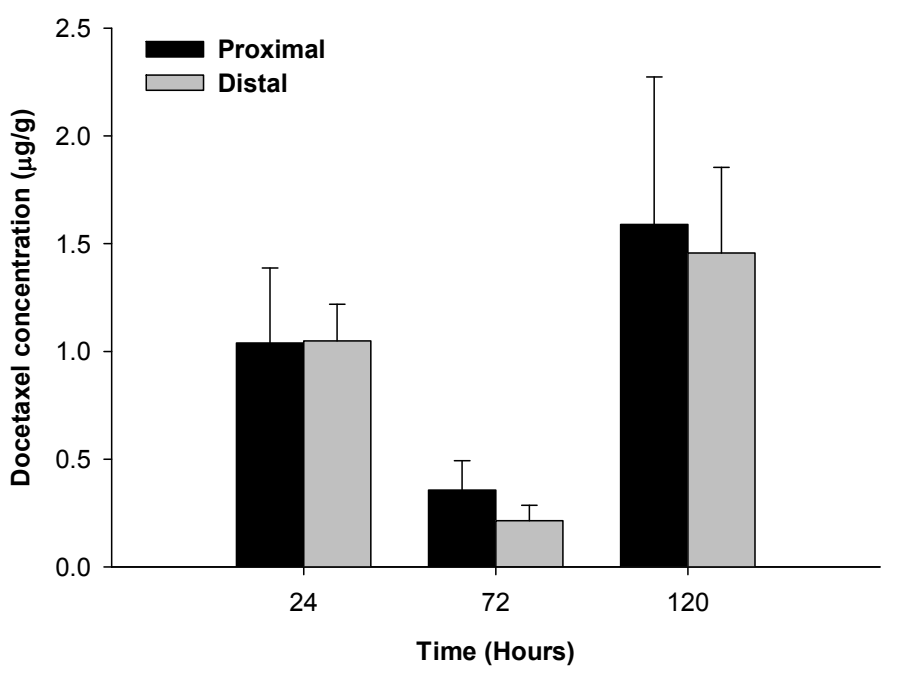


(C)

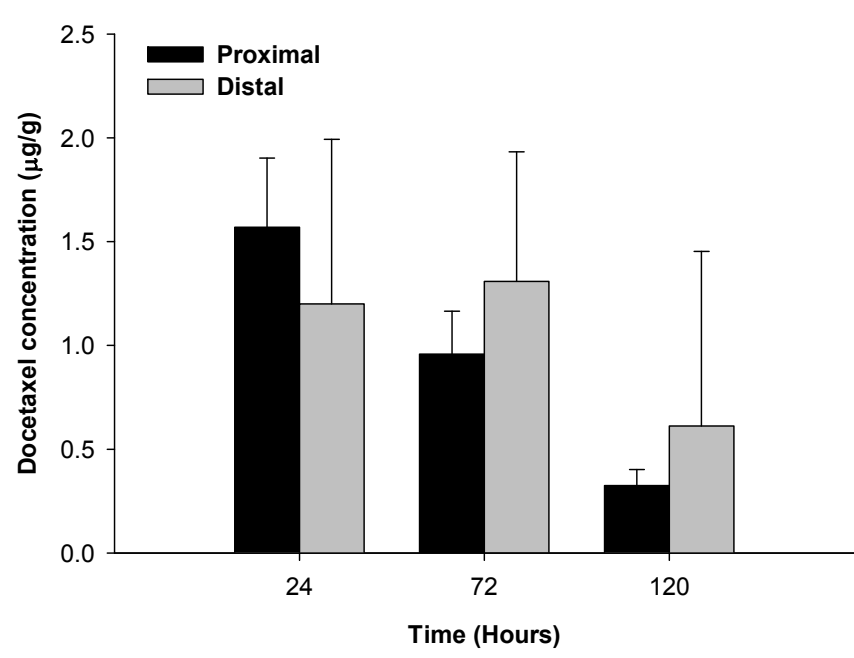

(D)

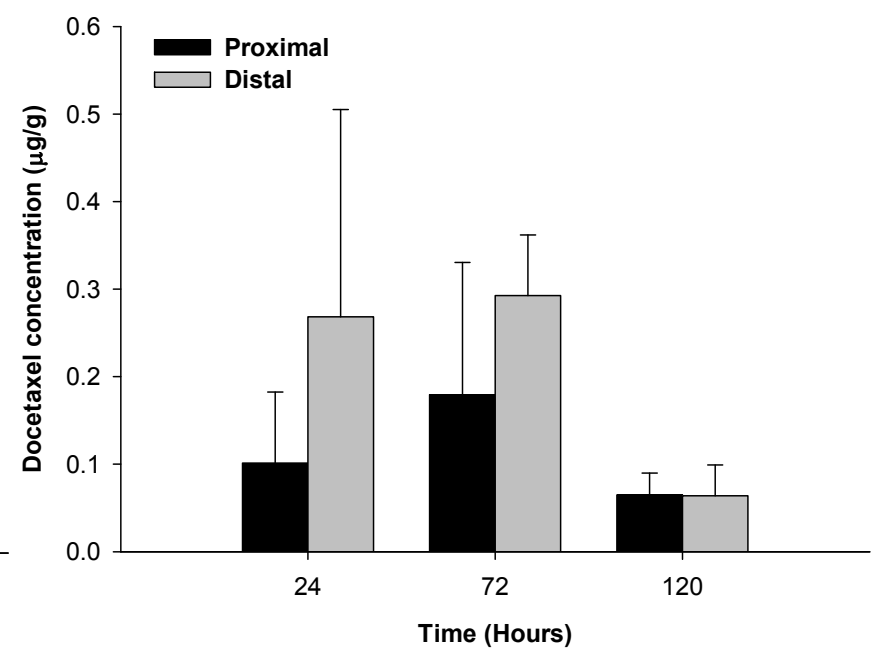

Figure 4. Concentrations of DTX in tissue sections that were proximal and distal to the site of injection of the PoLigel formulation (see Figure 1B) in female CD-1 mice (DTX dose: $7 \mathrm{mg} / \mathrm{kg}$ ). (A) Peritoneal layer, (B) liver, (C) intestine and (D) kidney. No statistically significant difference $(p>0.05)$ in DTX concentration between proximal and distal sites were seen. The results represent mean $\pm \operatorname{SD}(n=4)$.

Of these, hydrogels have been shown to enable the most significant improvements in drug retention, within the peritoneal cavity following IP administration. Implantable (30) and injectable (13) hydrogels have been developed by our laboratory for IP localized and sustained delivery of taxanes (i.e. paclitaxel and docetaxel). Sustained plasma drug levels have been observed in murine models for up to one month post administration of these hydrogel systems $(13,31)$. Furthermore, evaluation of efficacy in murine orthotopic models of ovarian cancer have demonstrated significant reduction in disease burden upon treatment with the taxanecontaining hydrogel systems when compared to treatment with the FDA approved formulations of these drugs $(10,12,13,33)$. Recently we have shown that sustained DTX exposure (i.e. via the PoLigel) results in greater antitumor efficacy than Taxotere ${ }^{\circledR}$ administration in ovarian cancer xenografts, which was due to greater tumor cell kill and reduced proliferation and angiogenesis (10). We believe that the differences seen in efficacy between the two formulations may be justified by their peritoneal drug distribution profile.

Following IP administration of either PoLigel or Taxotere $\AA$, high concentrations of DTX in the peritoneal layer and stomach were observed compared to other peritoneal tissues such as kidney, liver, spleen and intestine. The peritoneal layer is composed of mesothelium and connective tissue layers. The main transport route for drugs into the systemic circulation from the peritoneal cavity is through the capillaries found within the peritoneal layer $(34,35)$. Since this layer is largely composed of poorly vascularised connective tissue, the blood capillary density is low. High molecular weight lipophilic drugs such as DTX have a slow uptake rate from the peritoneal cavity as compared to other agents (36). This characteristically slow uptake of DTX into capillaries, compounded with the low blood capillary density of the peritoneal layer and sustained drug release from the PoLigel, results in greater drug accumulation within the connective tissue layers of the peritoneum compared to other tissues. Similar to our findings, Marchettini et al. (37) reported high concentrations of DTX (administered as Taxotere ${ }^{\circledR}$ ) in the abdominal wall (i.e. peritoneal layer) and in the omentum up to 24 hours following IP administration. The high drug concentrations in the peritoneal cavity and homogenous drug tissue distribution (i.e. distal and proximal to the PoLigel) suggest the application of the PoLigel formulation in the treatment of cancers confined to the peritoneal cavity such as ovarian, colorectal and gastrointestinal which in advanced stages form metastatic lesions along the peritoneal surface (38). In addition, damage to the peritoneal surface due to cytoreductive surgery of the lesions 
is known to encourage further peritoneal metastasis (39). Overall, sustained drug levels observed in the peritoneal layer after treatment with the PoLigel could allow for greater efficacy in advanced stage metastatic peritoneal cancers.

Drug concentrations in the ovaries were not examined in the present study, as the application of our treatment strategy is stage IV (advanced) ovarian cancer. At this stage of the disease, tumors have metastasized beyond the ovaries throughout the peritoneal cavity (40). Adjuvant chemotherapy, which is what the PoLigel is being developed for, occurs after debulking surgery, during which the ovaries are removed (41).

DTX is highly hydrophobic and, for this reason, the non-ionic surfactant polysorbate 80 is currently used as the formulation vehicle for this drug (Taxotere ${ }^{\circledR}$, Sanofi-Aventis). Post administration polysorbate 80 forms nano-sized micelle-like structures that solubilize DTX (17). As shown in the tissue distribution profiles (Figure 3A) this formulation results in some retention of the drug within peritoneal tissues. However, this surfactant is associated with hypersensitivity reactions, and has been shown to alter cellular uptake, tissue distribution, and the activity of DTX (10, 17-19). Therefore, to further prolong drug retention within the peritoneal cavity and to circumvent these issues drug delivery strategies such as PoLigel must be considered.

\section{CONCLUSIONS}

The influence of two different formulation strategies (i.e. Taxotere ${ }^{\circledR}$ and PoLigel) on the peritoneal and plasma levels of DTX was evaluated. For the first time the long term (i.e. $>24$ hours) tissue and plasma distribution of DTX was assessed following IP administration of Taxotere ${ }^{\circledR}$. Importantly, 72 hours following the IP injection of Taxotere ${ }^{\circledR}$ the drug levels in plasma were undetectable and only detectable levels in the intestine, stomach and peritoneal layer tissues were observed. In contrast, sustained DTX tissue and plasma levels were observed following IP administration of the PoLigel over the 120 hour period. In summary, the PoLigel formulation increases tissue and plasma drug retention and provides sustained DTX levels compared to the current clinically used Taxotere ${ }^{\circledR}$ formulation, which may explain the improvement in efficacy that has been observed in our previous studies.

\section{ACKNOWLEDGEMENTS}

This work was supported by a research grant obtained from the Canadian Cancer Society, Ontario Division. P. Zahedi is grateful to the Ontario Graduate Scholarship for a post-graduate scholarship. R. De Souza is grateful to the Ontario Graduate Scholarship and Ovarian Cancer Canada's Teal Heart Scholarship Fund for post-graduate scholarships.

\section{REFERENCES}

1. Ceelen WP, Flessner MF. Intraperitoneal therapy for peritoneal tumors: biophysics and clinical evidence. Nat Rev Clin Oncol, 2010; 7:108-115.

2. Ali SM, Hoemann MZ, Aube J, Georg GI, Mitscher LA, Jayasinghe LR. Butitaxel analogues: Synthesis and structure-activity relationships. J Med Chem, 1997; 40:236-241.

3. Baker SD, Sparreboom A, Verweij J. Clinical pharmacokinetics of docetaxel - Recent developments. Clin Pharmacokinet, 2006; 45:235252.

4. Royer I, Monsarrat B, Sonnier M, Wright M, Cresteil T. Metabolism of docetaxel by human cytochromes P450: Interactions with paclitaxel and other antineoplastic drugs. Cancer Res, 1996; 56:5865.

5. Morgan RJ, Doroshow JH, Synold T, Lim D, Shibata S, Margolin K, Schwarz R, Leong L, Somlo G, Twardowski P, Yen Y, Chow W, Lin P, Paz B, Chu D, Frankel P, Stalter S. Phase I trial of intraperitoneal docetaxel in the treatment of advanced malignancies primarily confined to the peritoneal cavity: Dose-limiting toxicity and pharmacokinetics. Clin Cancer Res, 2003; 9:58965901.

6. Fushida S, Nao F, Kinami S, Ninomiya I, Fujimura T, Nishimura G, Ohta T, Yokogawa K, Miyamoto K, Miwa K. Pharmacologic study of intraperitoneal docetaxel in gastric cancer patients with peritoneal dissemination. Gan To Kagaku Ryoho, 2002; 29:1759-1763.

7. Lukas G, Brindle SD, Greengar.P. Route of absorption of intraperitoneally administered compounds. J Pharmacol Exp Ther 1971; 178:562$\&$.

8. Flessner MF. Peritoneal transport physiology insights from basic research. J Am Soc Nephrol, 1991; 2:122-135. 
9. Davis AJ, Tannock IF. Repopulation of tumor cells between cycles of chemotherapy: a neglected factor. Lancet Oncol, 2000; 1:86-93.

10. De Souza R, Zahedi P, Moriyama EH, Allen CJ, Wilson BC, Piquette-Miller M. Continuous docetaxel chemotherapy improves therapeutic efficacy in murine models of ovarian cancer. Mol Cancer Ther, 2010; 9:1820-1830.

11. Kuh HJ, Jang SH, Wientjes MG, Weaver JR, Au JLS. Determinants of paclitaxel penetration and accumulation in human solid tumor. J Pharmacol Exp Ther, 1999; 290:871-880.

12. Vassileva V, Moriyama EH, De Souza R, Grant J, Allen CJ, Wilson BC, Piquette-Miller M. Efficacy assessment of sustained intraperitoneal paclitaxel therapy in a murine model of ovarian cancer using bioluminescent imaging. $\mathrm{Br} \mathrm{J}$ Cancer, 2008; 99:2037-2043.

13. Zahedi P, De Souza R, Piquette-Miller M, Allen C. Chitosan-phospholipid blend for sustained and localized delivery of docetaxel to the peritoneal cavity. Int J Pharm, 2009; 377:76-84.

14. Mohamed F, Stuart OA, Sugarbaker PH. Pharmacokinetics and tissue distribution of intraperitoneal docetaxel with different carrier solutions. J Surg Res, 2003; 113:114-120.

15. Yokogawa K, Jin MJ, Furui N, Yamazaki $M$, Yoshihara H, Nomura M, Furukawa H, Ishizaki J, Fushida S, Miwa K, Miyamoto K. Disposition kinetics of taxanes after intraperitoneal administration in rats and influence of surfactant vehicles. J Pharm Pharmacol, 2004; 56:629-634.

16. Kamijo $\mathrm{Y}$, Ito C, Nomura M, Sai Y, Miyamoto K. Surfactants influence the distribution of taxanes in peritoneal dissemination tumor-bearing rats. Cancer Lett, 2010; 287:182-186.

17. Engels FK, Mathot RAA, Verweij J. Alternative drug formulations of docetaxel: a review. AntiCancer Drugs, 2007; 18:95-103.

18. Hennenfent KL, Govindan R. Novel formulations of taxanes: a review. Old wine in a new bottle? Ann Oncol, 2006; 17:735-749.

19. van Zuylen L, Verweij J, Sparreboom A. Role of formulation vehicles in taxane pharmacology. Invest New Drugs, 2001; 19:125-141.

20. Hirano K, Hunt CA. Lymphatic transport of liposome-encapsulated agents - effects of liposome size following intraperitoneal administration. J Pharm Sci, 1985; 74:915-921.

21. Kohane DS, Tse JY, Yeo Y, Padera R, Shubina M, Langer R. Biodegradable polymeric microspheres and nanospheres for drug delivery in the peritoneum. J Biomed Mater Res Part A, 2006; 77A:351-361.

22. Tsai M, Lu Z, Wang J, Yeh TK, Wientjes MG, Au JLS. Effects of carrier on disposition and antitumor activity of intraperitoneal paclitaxel. Pharm Res, 2007; 24:1691-1701.

23. Armstrong DK, Fleming GF, Markman M, Bailey $\mathrm{HH}$. A phase I trial of intraperitoneal sustainedrelease paclitaxel microspheres (Paclimer $\left.{ }^{\circledR}\right)$ in recurrent ovarian cancer: A Gynecologic Oncology Group study. Gynecol Oncol, 2006; 103:391-396.

24. Yeo Y, Kohane DS. Polymers in the prevention of peritoneal adhesions. Eur J Pharm Biopharm, 2008; 68:57-66.

25. Fulzele SV, Satturwar PM, Dorle AK. Study of the biodegradation and in vivo biocompatibility of novel biomaterials. Eur J Pharm Sci, 2003; 20:53-61.

26. Grayson ACR, Voskerician G, Lynn A, Anderson JM, Cima MJ, Langer R. Differential degradation rates in vivo and in vitro of biocompatible poly(lactic acid) and poly(glycolic acid) homo- and co-polymers for a polymeric drug-delivery microchip. J Biomater Sci, Polym Ed, 2004; 15:1281-1304.

27. Hickey T, Kreutzer D, Burgess DJ, Moussy F. In vivo evaluation of a dexamethasone/PLGA microsphere system designed to suppress the inflammatory tissue response to implantable medical devices. J Biomed Mater Res, 2002; 61:180-187.

28. Ho EA, Vassileva V, Allen C, Piquette-Miller M. In vitro and in vivo characterization of a novel biocompatible polymer-lipid implant system for the sustained delivery of paclitaxel. J Control Release, 2005; 104:181-191.

29. Yeo Y, Ito T, Bellas E, Highley CB, Marini R, Kohane DS. In situ cross-linkable hyaluronan hydrogels containing polymeric nanoparticles for preventing postsurgical adhesions. Ann Surg, 2007; 245:819-824.

30. Grant J, Blicker M, Piquette-Miller M, Allen C. Hybrid films from blends of chitosan and egg phosphatidylcholine for localized delivery of paclitaxel. J Pharm Sci, 2005; 94:1512-1527.

31. Lim Soo P, Cho J, Grant J, Ho E, Piquette-Miller M, Allen C. Drug release mechanism of paclitaxel from a chitosan-lipid implant system: Effect of swelling, degradation and morphology. Eur $J$ Pharm Biopharm, 2008; 69:149-157.

32. Cho J, Grant J, Piquette-Miller M, Allen C. Synthesis and physicochemical and dynamic mechanical properties of a water-soluble chitosan derivative as a biomaterial. Biomacromolecules, 2006; 7:3548-3548.

33. Vassileva V, Grant J, De Souza R, Allen C, Piquette-Miller M. Novel biocompatible intraperitoneal drug delivery system increases tolerability and therapeutic efficacy of paclitaxel in a human ovarian cancer xenograft model. Cancer Chemoth Pharm, 2007; 60:907-914. 
34. Flessner MF. The transport barrier in intraperitoneal therapy. Am J Physiol-Renal Physiol, 2005; 288:F433-F442.

35. Van der Speeten K, Stuart OA, Sugarbaker PH. Pharmacokinetics and pharmacodynamics of perioperative cancer chemotherapy in peritoneal surface malignancy. Cancer J, 2009; 15:216-224.

36. de Bree E, Rosing H, Michalakis J, Romanos J, Relakis K, Theodoropoulos PA, Beijnen $\mathrm{JH}$, Georgoulias V, Tsiftsis DD. Intraperitoneal chemotherapy with taxanes for ovarian cancer with peritoneal dissemination. Eur J Surg Oncol, 2006; 32:666-670.

37. Marchettini P, Stuart OA, Mohamed F, Yoo D, Sugarbaker PH. Docetaxel: pharmacokinetics and tissue levels after intraperitoneal and intravenous administration in a rat model. Cancer Chemother Pharmacol, 2002; 49:499-503.

38. $\mathrm{Lu} \mathrm{Z}$, Wang J, Wientjes MG, Au JLS. Intraperitoneal therapy for peritoneal cancer. Future Oncol, 2010; 6:1625-1641.

39. Oosterling SJ, van der Bij GJ, van Egmond M, van der Sijp JRM. Surgical trauma and peritoneal recurrence of colorectal carcinoma. Eur J Surg Oncol, 2005; 31:29-37.

40. Hennessy BT, Coleman RL, Markman M. Ovarian cancer. Lancet, 2009; 374:1371-1382.

41. Roett MA, Evans P. Ovarian Cancer: An Overview. Am Fam Physician, 2009; 80:609-616. 